\title{
Decolonising Subalternity through Effective History in Ishmael Reed's Yellow Back Radio Broke-Down and Sonallah Ibrahim's Zaat
}

\author{
Dr. Naeema Abdelgawad \\ Assistant Professor \& Independent Researcher \\ Literature and Translation \\ Cairo, Egypt \\ n_gawad@hotmail.com
}

In Section One of Manifesto of the Communist Party, Karl Marx and Friedrich Engels, formulating a comprehensive theory of history, contend:

The history of all hitherto existing society is the history of class struggles. Freeman and slave, patrician and plebeian, lord and serf, guild master and journeyman, in a word, oppressor and oppressed, stood in constant opposition to one another, carried on an uninterrupted, now hidden, now open fight. (91)

Marx and Engels believe that in any society, history marks a conflict between two struggling opposites; noting that the one in the privileged position oppresses the one who is not. Regretfully, that type of struggle never subsides; it seems to be perpetual as it is, sometimes, 'open' and, other times, hidden. The same is applied to colonised and excolonised countries. However, theirs is not a 'history of class struggles' but of a Master- 
Subaltern struggle. In this struggle, resisting subalternity is achieved through legitimating the existence of the Subalterns, a process that is realised by urging the colonisers or the colonisers' surrogates to recognise the subalterns' Being, which necessitates admitting not only the existence of the Subalterns, but also being conscious of them as individuals ${ }^{1}$. This is brought about by occupying a powerful position that is attained through heightening the Subaltern's sense of identity in the course of history. The result is, the paper argues, an active process of decolonising the Self, especially when an 'effective history' comes into existence to pave the way for the Subaltern to achieve self-realisation; as revealed in the Foucauldian thought and, also, the Hegelian and Heideggerian philosophy. The paper aims at analysing the empowerment process of the Subaltern in both Ishmael Reed's Yellow Back Radio BrokeDown (1969) and Sonallah Ibrahim's Zaat (1992) by comparing and contrasting different types of Subalterns as well as colonisers and colonisers' surrogates. The paper also sets out to explore the Subaltern's means of self-projection to acquire a position of power based upon history so as to examine the discourse of history in both African American and Egyptian postcolonial literature.

Keywords: Subalternity, Resistance, Remapping, Decolonise, Identity.

History is the quintessential element in the formation of any culture. It is the collective memory of any people bearing and delivering its communal identity; through delving the past, the future is projected. During colonial periods, the history of colonised countries has often been exposed to massive processes of distortion and engineering for the purpose of distancing the relationship of the past to the present, and of disrupting the line of inevitability inherent in the meaning of the past. As a consequence, all that is introduced in the present is a foreign past that relativises and undercuts the legitimacy of the present. Therefore, the history of Subaltern nations becomes bound to a status of constant 'mimicry' of 
a certain subject of Westerncentric history; a 'mimicry' that even "marks those moments of civil disobedience within the discipline of civility" (Bhabha, "Signs" 104). Consequently, subalternity becomes not only an imposed practice but also an inescapable fact; a grievous Consciousness which everyone promotes, including the historians in the colonised and ex-colonised nations. Dipesh Chakrabarty asserts that any historian in a Subaltern nation is condemned to knowing [the West] as the original home of the 'modern,' whereas the [Western] historian does not share a comparable predicament with regard to the pasts of the majority of humankind. This follows everyday subalternity of non-Western histories. (385)

Such subalternity is promoted through colonial palimpsestic practices ${ }^{2}$ overwhelming the history of the colonised and ex-colonised nations. Theirs is a 'history' that "is exposed to sweeping processes of erasures jeopardizing the entities of the postcolonial realms. The traces of colonialism that manifests itself in form of coterminous ideologies occupy a position of dominance" (Rabasa 358). Nonetheless, the Subaltern in the struggle for recognition finds in the imperfect erasures a source of hope; as the Subaltern's peripheral past is exhumed so as to "[reconstitute] or [reinvent] the world from native points of view" (Rabasa 358). At the same time, motivation and intent are considered because "they often overlap in conflicting ways" (Menon 35). In the course of such a struggle, Foucauldian and Hegelian theories overlap as they focus upon the issue of history as an instrument of recognition that is, in turn, the basis of resisting subalternity.

Foucault considers history a form of knowledge as well as a form of power. It is based upon a Consciousness of a certain truth about the past that is represented in writing. Thus, the cornerstone of such a system of truth and meaning is the statement, l'enoncé. However, a discursive formation, continually, generates new statements and some of these usher in 
changes in the discursive formation that may or may not be realised. Therefore, to describe a discursive formation, Foucault also focuses on expelled and forgotten discourses that never happen to change the discursive formation. The difference to the dominant discourse also describes it. Borrowing Foucault's language, genealogical investigations ${ }^{3}$ in Foucault's approach of "effective history" are attempts to assist with the "insurrection" of "subjugated knowledges" against "regimes of thought" (Foucault, Two Lectures 20).

Thus, specific systems that determine the types of the emerging statements can be described. Similarly, the Subalterns in the colonised and ex-colonised nations give rise to expelled and forgotten discourses, or stories, without disrupting the discursive formation of their engineered dissoluble forms of history. Yet, the result is the appearance of new meanings within the discursive formation of the enonce [in this case the enoncé is the history of the Subaltern]. Thus, the natives can change the discursive formation of their image as Subalterns. As for their history, it appears as a succession of epistémes which are a source of power. Foucault argues:

An event, consequently, is not a decision, a treaty, a reign, or a battle but the reversal of a relationship of forces, the usurpation of power, the appropriation of a vocabulary turned against those who had once used it, a feeble domination that poisons itself as it grows lax, the entry of a masked 'other'. ("Nietzsche" 88)

Foucault argues that the appearance of an effective history, which takes the form of epistémes of power, is possible because it is based upon events. It is worthy to mention that an event may not appear important; yet, it may have the power to highlight a forgotten or 
expelled fact which if brought to the surface, it may change the 'relationship of forces'; underline how power was usurped; or even create a new usage for the vocabulary that those in power promote so as to place them in an advantaged position. In accordance, the history of the Subaltern will be able to penetrate the engineered dissoluble forms of history that is moulded by the coloniser as if it were a 'masked other' that will soon assert his Being. Employing this Foucauldian approach, a new kind of history, a "general history" will supersede the "global history" whose objective is to "describe the particularity of practices, the play of their relations, the form of their dependencies" which would serve the marginal history of the subalterns (Foucault, "History" 240). Thus, the world would be geared to think differently about it; that is the first step towards recognising the Being of the Subaltern. In this respect, Heidegger in "Letter on Humanism" contends:

Thinking as such is bound to the advent of Being, to Being as advent, Being has already been dispatched to thinking. Being is as the destiny of thinking. But destiny is in itself historical. Its history has already come to language in the saying of thinkers. (Heidegger 307)

To Heidegger, Being is a matter of thinking and also a destiny and these are the constituents of history. Moreover, recognition is created and transferred throughout the economy of 'language' through which a statement would be passed among others as true. This refers to the fact that the historicity of human existence is based upon recognition.

Recognition, as elucidated in the Hegelian philosophy, has ever been the ultimate goal of postcolonial people suffering from degrading subalternity created within time and space. Hence, the dynamics of human reality which is structured upon Consciousness and Being is 
connected to the concept of time, or, in other words, history. Time, in Hegel's philosophy, is a loophole towards understanding the nature and structure of Consciousness. "Time," says Hegel, "appears as Spirit's destiny and necessity, where spirit is not yet complete within itself" (The Phenomenology 800). Hegel believes that the human spirit, which is the essence of the nature and the structure of Consciousness leading to recognition, is incomplete. However, Time is still the confinement within which Spirit moves; Time is its destiny. Similarly, in case of postcolonial nations, history, i.e., Time is the destiny of the Subaltern, in other words, Spirit.

Ishmael Reed and Sonallah Ibrahim in Yellow Back Radio Broke-Down and Zaat, respectively, introduce a map of postcolonial realms in today's world. They use history as a tenor depicting the assiduous attempts of the Subalterns to attain recognition in a space that places their Being in an inferior position and deprives their Consciousness of its dynamism. Ishmael Reed is an African American novelist, poet, essayist, editor, college professor and dramatist. In an interview with Reed in 1972, John O'Brien describes him as "one of America's most distinguished innovative fictionists and has established himself as the aesthetic spokesman of black experimental fiction" (25). Innovation is, in fact, the landmark of Reed's works; his postcolonial concerns are reflected in his revolutionary stances in almost every aspect of his literary career. His writings target breaking the molds into which the white system has locked his African American natives by exhorting black writers to flee the cultural Slave quarters and to develop non-Western literary standards.

Ishmael Reed's creative process springs out of adopting a multicultural position. Unlike many African American writers, whose ultimate zeal is armed revolution and holding the banner of nationalism, Reed places at the top of his priorities the reform of imagination 
rather than political and social upheavals. Reed's fiction satirises the sham values of the social and cultural system to which he belongs. The objects of his attack are Christianity, Western art and morality, the hypocrisy of democratic ideals, American history, and the tyrannical myths that shape the American mind. To this end, Reed invents forms and techniques, which he insists on calling voodoo aesthetics.

Considering Sonallah Ibrahim, he is an Egyptian novelist and a social critic whose works has been translated into many languages. He is "celebrated in the local and international literary scenes as one of the most prolific - and oftentimes propheticchroniclers of modern Cairene, Egyptian, and Arab life" (Shafy). He served a five-year sentence, from 1959 to 1964, because of his involvement with the Communist Party in Egypt. He always refers to this incarceration period as some sort of university, saying that it brought him in contact with inmates from all walks of life, from college professors to labourers and peasants. He attended classes on hieroglyphics, history and French. He also read books that had been smuggled inside the prison walls by enterprising inmates (Hassen). His writings defy the Arabic literary focus on poetic language and rhythms. His objective is representing the image of a non-traditional coloniser. "[Ibrahim's style] had a lot to do with disillusionment with how language and discourse, in general, were being manipulated by power," says Professor Samia Mehrez, "his major enterprise was how to create or invent a language that would depict a horrid, sordid reality that was not being reflected or expressed through the dominant modes of discourse" (qtd. in Hassen).

Ibrahim's fiction mainly belongs to the literary genre "Prison Literature" which appeared in postcolonial Egypt after the evacuation of the English coloniser, by the end of king Farouk's hegemony when the nationalists assumed power. A political novelist as he is, 
Ibrahim leads his readers through the eventful past and present of Egypt ("The flying drapes"). Ibrahim's writings, acclaimed in the circles of Arabic literature, are sharp, clear and dense ("Zaat by Sonallah Ibrahim"). They blend satirical black humour with a documentary style, and probes provocative matters such as prison life, revolution, civil war, and dominance of multicultural corporations. Ibrahim always asserts that his writing is driven by the desire to understand the working of complex systems - whether multicultural corporations, crowded apartment building, or insect colonies, referring to his famous collection of children stories on insect colonies. It is also much better for him to entertain his readers and energise them politically while discussing such vital issues (Hassen).

Reed and Ibrahim set out themselves for the task of resisting the denigrating influence that mortifies the body and the soul of their people and stamp them with subalternity. Compared to freedom fighters in Kenya ${ }^{4}$, they realise that history is a vital instrument helping them destroy the stereotypical Manichean image of their natives. "I think," confirms Reed, "my knowledge of history, real history makes me a stronger person" ("A Conversation with John Domini," Conversations 140). As for Sonallah Ibrahim, his works always shed light upon the details of a certain period of history. Obviously, it seems that he believes that history is an educator if publicly promulgated; it would help people evade subalternity. Reed's Yellow Back Radio Broke-Down and Ibrahim's Zaat represent not only the outside features of subalternity but also their inside. Both novels produce an active documentation of the content and expression of history through documenting the status quo as well as reviving the social rituals engendering a form of a continuous history because the past is conducive to the present. Foucault argues: 
Continuous history is the indispensable correlative of the founding function of the subject: the guarantee that everything that has eluded him may be restored to him, the certainty that time will disperse nothing without restoring it in a reconstituted unity; the promise that one day the subject - in the form of historical consciousness - will once again be able to appropriate, to bring back under his sway, all those things that are kept at a distance by difference, and find in them what might be called his abode. (Foucault, Archeology of Knowledge 12)

Foucault thinks that continuous history is quintessential because it guarantees that nothing will be lost and nothing will be forgotten by the passage of time. All the events form a coherent unity to the extent that whatever took place a long time ago would never be forgotten because it is included within a scheme of a continuous history. Reed and Ibrahim make of Yellow Back Radio Broke-Down and Zaat, respectively, schemes for a continuous history that registers events, which takes place in their societies. They appear just like two intellectual historians whose knowledge of the past and ability to develop and control it become a source of power that they zealously transfer to their people and in the process; they also gain the same power.

In Yellow Back Radio Broke-Down and Zaat, history is represented almost according to the same method of the freedom fighters; exactly, making use of the direct expedience of oral tradition and reviving the social rituals that interact with each other. The result is avoiding the introduction of a homogeneous flat documentation of history and, accordingly, paving the way to an extensive aura of resistance based upon recognition. In fact, the title of both novels is a gateway to the use of history as a discourse of power gearing resistance of 
subalternity. In Yellow Back Radio Broke-Down, Reed intends to revive the oral tradition. He suggests that 'yellow back' refers to the popular dime novels; 'radio' refers to the novel's oral discontinuous form; and 'broke-down' means dismantled. Reed aspires to assault America in an attempt to unmask its cultural structure. As for Ibrahim, the title of the novel is also an instrument of historicising. 'Zaat' is an ambiguous word meaning in Arabic either 'self,' 'identity,' or 'owner of.' The name refers to the fact that a person should exist so as to resist; Ibrahim asserts the necessity of Being.

Compared to freedom-fighters, both novelists make use of story-telling to educate their natives about the means of resistance. The beginning of Yellow Back Radio Broke-Down is compared to the beginning of a radio programme.

Folks. This is here the story of the Loop Garoo Kid. A cowboy so bad he made a working posse of spells phone in sick. A bull whacker so unfeeling he left the print of winged mice on hides of crawling women. A desperado so ornery he made the Pope cry and the most powerful of cattlemen shed his head to the Executioner's swine. $(Y B 9)^{5}$

The protagonist of the novel is not a conventional, melodramatic, good character. The Loop Garoo Kid is depicted as a brutal westerner who practices voodoo and mixes love with cruelty; as he stamps the women with whom he makes love with a mark of a winged mouse. The Loop Garoo Kid is also capable of using his powers of magic to trouble the others and to turn their lives miserable. Nonetheless, Reed asserts that his protagonist is not a villain: "Now, he wasn't always bad" (YB 9). The Loop's character is compared to that of the blacks who work in the field of resistance. Reed's protagonist is an attempt to keep his black history 
revived against underway colonial movement to suppress black voices. In a recent interview, Reed confirms:

Through the need to suppress a variety of black voices, the literary and cultural establishment engage in one-at-a-time-ism. So, the establishment still tries to control the direction of black culture by creating tokens, a remnant of the old Colonial strategy, which relies upon a few gifted assimilated natives to tell the colonial office which natives are reasonable and which are unruly. (Howell, 2018)

Reed is against the modern trend of suppressing black voices so as to cripple any further attempt to improve the self. Thus, his protagonist in a 'one-at-a-time' character that is both reasonable and unruly; a character that subverts any colonial strategy.

Similarly, in Zaat, Ibrahim is the omnipotent narrator of the whole work who intervenes every now and then in the course of the events; either to comment or explicate the situation.

We could begin Zaat's story from its natural beginning, that's from the moment she slid into our world bespattered with blood, and the shock, the first of many she would endure, that followed as she was lifted feet first into the air and given a hefty slap on the backside [My emphasis]. (Zaat 1)

Ibrahim assumes the role of the traditional storyteller whose presence helps the audience portray Zaat through what he utters. 
Reviving the social rituals in both novels pokes an aura of resistance and modernises the instruments of projecting the identity. They are devices of collective memory that are both anti-historical and anti-modern. Reed's and Ibrahim's objective is to crystallise such rituals so as to defy the "mimetic" mode of self-representation whose figures project a transition narrative that is constantly "grievously incomplete" (Bhabha, "Of Mimicry" 125). Away from any 'mimetic' mode, Reed invokes a simulacrum of his tradition in both form and content when he gives rise to voodoo, making it a gateway between Africa and the White World; it stems from the Old World passing to the new one. Through voodoo, the process of the Middle Passage is repeated to legitimate the existence of the Africans in the New World and provide them with power. The scenes of voodoo practicing produce an atavist spectacle. They are also considered "the renascence of a new corpus of sensibility that could translate and accommodate African and other legacies within a new architecture of cultures" (Harris 380). The voodoo scenes introduce the African legacy to an alien culture so as to be a coherent part of its structure.

In respect of technique, Reed has a special interest in creating a system of his own through which he can conjure the past in the present and mix them together while adorning them with a coating of history; he calls this voodoo aesthetics. Reed's studying material at the university is the source of his inspiration. He recalls, when "I went to the university I was imbued with Western culture, myth, and ideas. I admired Blake and Yeats, people who created their own systems, or revived their own cultures. So that's what I wanted to do ... I wanted to create a mythology closer to me" ("The Great Tenure Battle," Conversations 124). Reed resists his own and his natives' subalternity by the same weapon that the West uses so as to eternalise its culture. In a Foucauldian sense, Reed creates a new discursive formation of the type of knowledge with which he is nourished in college. He turns the Western-centric 
ideologies, techniques and also vocabulary, which are all used to perpetuate the Western culture, into a cornerstone for creating a mythology with which he revives his and his natives' history. Similar to Foucault, it seems that Reed believes that knowledge is power. Amazingly, Reed gains recognition and succeeds at creating his voodoo aesthetics when he employs the same techniques of the West. In Yellow Back Radio Broke-Down, the events run within the era of the old Wild West in America. However, an anachronistic vision wraps the timing, turning the whole work into a phantasmagoric piece whose protagonist is a black lone westerner; in contradiction to the traditional features of this epoch when the whites were the loners in the Wild West and the blacks were the slaves. According to John O'Brien, "revolution is indeed what Reed seeks, but not the political upheavals his wary critics have attributed to him. He is instead after a reform of 'imagination,' and to this end his fiction satirises and takes out after the emblems of the cultural establishment and its underlying values" (25). Reed's works intend to ignite a revolution; not a political revolution, but one with which he may 'reform' the 'imagination' of his natives. Therefore, his works are satiric and target the values and the emblems of the western culture. In consistence, Reed has established himself the aesthetic spokesman for black experimental fiction through which he teaches his natives innumerable facts about their culture and independence. Unlike his contemporaries, he pines not for a private vision; but for syncretising the black and the white cultures.

Similarly, Ibrahim intends to revive the social rituals through representing the everyday life of a woman whose household is a replica of almost the other households in the entire nation. He also invokes the particularities of the Egyptian society; the rituals of birth, circumcision, wedding night, bringing up females, birthday parties and belief in genies and exorcism as well as the evasive and humiliating attitude of the civil servants. Despite the fact 
that such practices might enfold negative aspects, they are accounted as essential formative components in the set of practices and beliefs shaping the national identity. They might be metonymically called an Egyptian voodoo. Zaat's background is a time span extending from the sixties of the twentieth century up to the nineties or even extends to the present. Ibrahim's intention is to historicise the most important three phases in modern Egypt after the evacuation of the colonising powers and the royal regime. Creating the evidence on the facts he cites, Ibrahim annexes each chapter by excerpts from the Egyptian newspapers supporting the social and political facts he mentions. Whatever incidents and situations he mentions in Zaat are real; they are derived from the heaps of newspapers that are accumulated in his apartment. The background Ibrahim creates is indispensable.

Sonallah Ibrahim accurately mixes historical documentation, from one side, and the events of the novel, from the other side, in a way that is impossible to tear away one side from the other so as to individually deal with it, as claimed some because both of them represent the organic unity of the novel. (El Khouly 88)

Ibrahim's Zaat is, remarkably, structured; historical facts are mixed with the events of the novel so as to create a coherent unity that represents both the body of the novel and the author's comment upon the status quo.

It is through reviving the social rituals that Ibrahim represents the history of the liberated Egypt, which is fettered with the shackles of the aftermath of colonialism. During the colonialist era in Egypt, the Egyptians fetishistically long for national liberation through starting revolutionary decolonisation capable, in Frantz Fanon's memorable phrase, of 
"change[ing] the order of the world" (Black Skin 36). Currently, the situation is different; the decolonisation process should start from within; from souls that are blurred with a hideous feeling of subalternity, which divides the nation into either oppressed Subalterns or coloniser surrogates. Essentially, the coloniser surrogates are the modern form of the Subalterns of the colonising powers, whether such powers were multicultural corporations or corrupt civil servants who jeopardise the safety and the interests of their natives for the sake of serving their ends.

Having collected the necessary material, Reed and Ibrahim begin passing it as true or known among the others through the economy of discourse, which is, according to Foucault, a source of power. Thus, Ibrahim bases Zaat upon the technique of oral storytelling and he appears as a conventional storyteller who is keen to influence the audience. On the other hand, Reed, unconventionally, writes his novel as a dialogue that is invaded with very slight descriptions. Accordingly, an active process of documentation begins so as to create an effective epistéme of power compelling the colonisers who are a typical version of Hegel's concept of a Master, to recognise them.

The presence of a non-traditional coloniser in Yellow Back Radio Broke-Down and Zaat is introduced in form of a hegemonising Other who emphasizes their subalternity and fetishises their Manichaeism. Drag Gibson, in Yellow Back Radio Broke-Down, is a typical coloniser in a feudal disguise. He is "the richest man in the valley, with prosperous herds, abundant resources and an ego as wide as the Grand Canyon" (YB 17). Compared to any coloniser, he is cruel and unyielding whose ultimate target is to disband any union for the sake of subjugating everyone; including those whom he takes as inmates and whom he grants power and wealth so as to become his surrogates. In his presence, Drag's adherents show 
uttermost obedience and willingly discard their desire for recognition. Putting an end to the rise of the Kids at the hands of Drag Gibson costs the towners and the superiors, who assume the position of the coloniser surrogates, all their properties; as Drag Gibson forces them to sign everything to him. As a consequence, he guarantees the subalternity of everyone to him though he implements that under the sham guise of understanding and responding to the needs of his natives. Chinua Achebe asserts:

To the colonialist mind, it was always of the uttermost importance to be able to say: 'I know my natives,' a claim which implied two things at once: (a) that the native was really quite simple and (b) that understanding him and controlling him went hand in hand - understanding being a precondition for control and control constituting adequate proof of understanding. (58)

The colonisers who claim that they 'know' their natives are invective to their natives because their claim confirms that the natives are simple-minded; thus, it is easy to both understand and control them. Drag Gibson, similar to any coloniser claiming that he knows his natives, incarnates Chinua Achebe's perspective on the colonialist mind. Controlling everyone, Drag Gibson makes of the Marshal, the Doctor and all the cowpokes his puppets. He can commit whatever crime or atrocity and go unpunished. Being the only hegemonising power in town enables him to give himself the right to kill in cold blood his wives and whoever disturbs him as long as his surrogates cover up for him. "After all Drag it's your world completely now," avows the Marshal (YB 21). However, Drag's men are not satisfied with his hegemony. They only serve him out of greed, not love; as he promises to distribute his wealth over them after his death. Sarcastically, when Drag pretends that he died, the reaction of everyone is an overwhelming joy. The ghastliness of his hegemonising system is 
underlined when it is revealed that Drag Gibson, the master of the whole world, is sexually impotent and the source of his pleasure is kissing his mustang horse and beholding his wives having illegitimate affairs with other men. Reed satirises the capitalists whose financial powers direct the politics and the destiny of their natives.

The same problem of the hegemony of the colonial authority is introduced in Zaat, yet, not in form of the coloniser himself, but the coloniser's surrogates who are, in fact, the coloniser's puppets. Despite the fact that Egypt is a free country, it has fallen into what Frantz Fanon defines as the 'pitfall of national consciousness;' it is the status when the natives turn into another copy of the coloniser. Fanon asserts "these are the cracks in the edifice which show the process of retrogression that is so harmful and prejudicial to national effort and national unity" (Black Skin 86). The efforts that the natives exert to evacuate the colonisers are in vain because the natives fall in the 'pitfall of national consciousness' which has a negative influence upon the united national efforts and the national unity. Colonialism in Egypt factionalises the society and creates a hybrid world in which the class of the bourgeoisie-élite becomes informants to the first world. The members of such a class are only interested in their views, which they try to impose disregarding the differences between both worlds; i.e. their nation and the coloniser's country. However, when it is time to do anything for the good of their natives, the class of the bourgeoisie-élite, instantly, assumes the position of the coloniser and starts working for its own interest forgetting all about the natives. The members of the class of the bourgeoisie-élite, amazingly, define what they do as normative process and whatever resulting damages are ineluctable possibility in the process of advancement. Moreover, they place themselves at the position of the judge and the mentor whose opinion is irrevocable; on basis that they believe that they are in a position higher than that of their natives (Fanon, Black Skin 86-87). In brief, such a class is the modern version of 
the other whose place is the centre while sending the natives away to the margin robbed of their authoritative image.

Zaat's building is a replica of her district that is, in turn, a replica of the nation as a whole. The tenants of the building recoil from solving their most serious problems, which are that of the cats and the garbage. Each one of the neighbours seeks, instead, his personal interest, as well as, peace of mind. Evidently, the employee in the Ministry of Agriculture, the butcher, the army officer and El Shanqeety, who is an employee in the Heliopolis Local Council, make use of their positions, which are originally created to serve the public. They use the money they illegally gain to promote Western-centric ideals and to exacerbate those who cannot match them, as if enticing the others to betray their ideals because this is the only way to enjoy the same possessions. Such corrupt people are remarkable with their fancy apartments, luxurious consumer goods, and participation in what Ibrahim satirically calls 'the march of demolition and construction' in which they demolish the walls of the kitchens and toilets to cover these with colourful ceramic tiles, and change the old kitchens and toilets with modern ones; which are, certainly, imported. Even the schoolteacher, who is supposed to be a mentor and idol of many generations, participates in the process of demolishing whatever original for the sake of whatever imported. He contributes to the march of demolition and construction by showing off his imported consumer goods and extravagantly throwing food whose cost might modernise the whole underdeveloped neighbourhood. Sonallah Ibrahim believes that any attempt to imitate the West and to promulgate its ideals is failure. Therefore, he invents word combinations that force a smile on the readers' lips, such as 'the march of demolition and construction,' . . . 'sarmaka,' . . . 'kambasha,' . . . 'kandasha,' . . . etc. It seems that Ibrahim, latently, says that the imitators of the West, who are the modern version of the 
coloniser surrogates, are no more than a laughing-stock. It is also obvious that they show off to recompense their deficiencies.

Doctor Fresh is a full-fledged example of a coloniser-surrogate or commissioner of the West. In the past, he was shy and almost disheveled. When he returns back home after getting his Ph.D. degree from Europe, he develops a completely different attitude. He becomes a manifestation of Achebe's theory of the 'man of two worlds' ${ }^{6}$ but in the opposite sense; as Doctor Fresh and his likes "would always discard the mask of civilization when the crucial hour came and reveal his true face" (Achebe 58). Undoubtedly, such a face is not that of the native, but of the coloniser's surrogate. Doctor Fresh returns from Europe, an extremely stylish and imposing figure in a frightful manner that is reflected through his expensive clothes, gifts and ideology. He literally terrifies the others with his notions on nourishment. His style is compared to that of the colonisers'. He groups people around him by feigning that he works for their good; exactly, giving right and useful information about nutrition. However, the moment they are grouped around him, he betrays them by showing his true 'face' of arrogance and pretension. He quits his position as university professor and opens an agency for the biggest insecticide company in Switzerland, an agency that contributes to widening the range of pollution. Obviously, his method of propaganda-making is to pretend that he works for the good of the others. In reality, he deceives his natives so as to convince them that they cannot do without him; this is, of course, a prop in the colonial thought.

Abdul Meguid, Zaat's husband, offers a parallel portrait to that of Doctor Fresh. He is a sort of an offshore coloniser-surrogate. Similar to Doctor Fresh, he also plays the role of Mr. Elegant and Mr. Know-all. In his common conversations even with the semi-ignorant Zaat, he tends to drift to uttering well-known English words; like 'meaning', as well as, his 
famous 'of course,' which meaning has for long puzzled Zaat and her family. The irony is that he did not finish his university education. Therefore, assuming such haughty airs is not appropriate to his inferior social position. Unlike Doctor Fresh, Abdul Meguid is poor and weak. He is only capable of oppressing his weak wife and playing the role of the Master of the House. Abdul Meguid, Doctor Fresh, the corrupt employees and the butcher are the modern version of the bourgeoisie-élite, a class that has emerged, in Egypt, by the end of the seventies. The influence of this class has, and still, been a threat to the national entity and identity. The notions and the practices of the modern bourgeoisie-élite are not a source of power to the nation. On the contrary, they produce a crack in the social edifice because such a class identifies itself as Master. The more the bourgeoisie-élite infuse their ideologies into society, the more obscure they become to the natives. In fact, their notions create ambivalence, and their power is attainable through their difference; a game played before by the foreign colonisers. The authority of the bourgeoisie-élite is acquired through establishing an aura of discrimination that destroys the idea of native collectivity and, similar to the norms of colonisation, the part becomes representative of the whole only because of its difference. In Egypt, the discourse of history represents a colonised culture of hybrid subjects who still believe in Masters and Subalterns as an evitable fact. Ishmael Reed and Sonallah Ibrahim shed light upon the oppressing 'Other' that is incarnated in corruption and evil. In this context, social unisonance is a remote possibility.

The binaries of Master/Subaltern and Self/Other appearing in Yellow Back Radio Broke-Down and Zaat are rooted in the Hegelian notion of Unhappy Consciousness that took its historical material from the religious life of the Middle Ages and the mental attitude assumed under the dominion of the Roman Catholic Church and the Feudal Hierarchy. The notion of Unhappy Consciousness makes of religion an instrument to promote slavery. It 
preaches that a religious person should relinquish mundane pleasures and that entails disregarding social contradictions and the search for being equal to the class of the Masters because equality, justice and freedom are only granted by the supreme Master, i.e., God, and that they are the reward waiting for the pious in paradise (Kojève 252). The concept of free self-hood that turned into Unhappy Consciousness finds strong repercussions in history. Religion appears as another form of Coloniser or Master who maintains unjust subalternity when it is coupled with corruption. In Yellow Back Radio Broke-Down and Zaat, Feudal Hierarchy is an established fact-giving reign to the colonisers and the colonisers' surrogates. The Church in Yellow Back Radio Broke-Down is corrupt. It inhibits and disdains any sort of relief that might be even found in practicing real art. Out of this suffocating ambience, the Loop Garoo Kid flees. He prefers leading a bohemian type of life to returning back to Rome. He has lost confidence in the Church and its fine promises considering them ephemeral lies whose ugly face is soon uncovered. When the Pope visits the Loop in prison, the Pope introduces to him an enticing offer, which meets all the demands of the Loop.

[The Pope]: Loop, he sent me to do the interrogating ... I ask you one more time Loop end this foolishness and come home. He built a special district for you, red lights, and the works. He sent for some of your bohemian types to keep you and Diane company. You can start a commune if you want, get light, walk around nude, anything you want Loop, just so you satisfy the wench.

[The Loop]: No dice, baby. (YB 166)

The Loop refuses because he knows that it is the Pope and his Superior who originally forced him to leave and it is the Pope who guides the Loop's enemies to capture him. Notably, the Pope's insistence on taking the Loop back to Rome and the Pope's subsequent 
frustration are not out of pity or care, but out of the fear of being humiliated at the hands of the Superior.

Ok, Loop, the worldly Pope said rising, I should know that when you have your mind made up on something, nothing can change it. When I get back, he is really going to put me down.

[The Loop]: How's that?

[The Pope]: Make me crawl on my belly and kiss his feet. Some days Loop, I can't stand the place. People singing the same old hymns and he sits there performing the familiar spectaculars - everyday. I miss St. Peter's Chug-alugging fine brandy. With the gang jamming some strumpets. (YB 166)

The surprise, which is antithetical to whatever has been taken for granted, namely, the hegemony of the Pope and his position, is that the Pope is a Subaltern, too. Compared to the Loop, the Pope's real interest is art. Yet, he is not as courageous as the Loop; he cannot express freely his own desires and feelings. The Pope has to bear humiliation and to mortify his senses and desires to which he nostalgically looks and yearns. The Pope's character deconstructs the logocentric image of a Pope as almost supernatural and perfect creature who is about to be a demi-god. His active self-protection is a systematic scheme of obedience.

Considering the town of Yellow Back Radio, in the current materialistic world domineered by the capitalist Drag Gibson, religion does not only retreat to the rears, but also becomes a useless subservient. Preacher Rev. Boyd tries hard to modernise the concept of religion so as to make it closer to the hearts of people. He assiduously connects it to dominant modern discourse. Preacher Rev. Boyd tries hard 
with the kids and the town's heathen, how he'd smoke hookahs with them brats and get stoned with Chief Showcase the only surviving injun and that volume of hip pastoral poetry he's putting together, Stomp Me O Lord. He thought that Protestantism would survive at least another month and he is tearing up the Red-Eye and writing more of them poem trying to keep up with the times. ( $Y B$ 21)

Rev. Boyd tries to mingle with all the classes of society through imitating their language and approaching their personal tendencies. Yet, his efforts are not exerted for the sake of reviving the concept of religion as a source of relief, but for attaining a position of power in a civilisation that neglects the religious discourse which has, for long periods of time, subjugated the Western culture and directed its motives and concepts. Remarkably, Preacher Rev. Boyd never succeeds because his piety is a sham guise of a corrupt personality pursuing mastery even if this might be conducive to the destruction of the essence and dictations of religion. Finding that there is not any possibility to win back this lost mastery, Rev. Boyd, like everybody else, recognises Drag Gibson as a Master under whose hegemony he might be granted some power. He never deters Drag Gibson from committing atrocities but rather promotes Drag's ideologies and participates in the unjust fight against the Loop Garoo Kid.

Zaat also faces the same problem of Unhappy Consciousness but in a more binding manner. According to Ibrahim, religion in the Egypt during the eighties domineered and controlled the Egyptian social life. However, this is not always a sign of piety and compassion; as whoever falls under the grip of the people wearing a pious mask is unhappy. Sonallah Ibrahim epitomises all these notions in the toy episode. He depicts the shop where 
Zaat buys the toy as if it were a holy place. Outside the shop, there is a microphone whose booming voice calls people to "believe in Allah and to eschew worldly pleasures" (Zaat 169). The saleswomen are angel-like figures who wear 'hegab'. As for the shop owner, he surrounds himself with a hallow of piety that prods the common people to think of him a great religious figure: he wears the attire of pious Moslems, mutters all the time appropriate Quoranic verses and Prophetic Traditions, and stresses the articulation points of the letters which gives Zaat the impression that it is the Islamic articulation of words. His appearance does not only deceive Zaat, but also many others who consider his shop a source of light and knowledge where they would go to it to know the position of Shariah law on worldly matters. However, this hallow is maintained as long as nothing interferes with his personal interests. The moment Zaat demands her right to change the flawed toy, the owner's hallow vanishes and the saint turns into a demonic figure who rudely and harshly refuses to change the toy. As for the pair of angels, i.e., the saleswomen, they almost help expelling Zaat from their Eden, which is the shop, where her rights are denied and she is cheated.

Reed's process of documenting the history of the Subalterns takes a phantasmagoric perspective illustrating the past and the present of not only the Africans in America, but also the other nationalities appearing at the background as a chaos of forms whose assembly gives an honest, yet, latent representation of the status quo. Reed's the Loop Garoo Kid is an imaginary character living in a multi-cultural harmonious society of fraternity, equality and freedom. Tearing such a guise, it is evident that discrimination prevails. In fact, Reed historicises the actual situation of the integrated blacks and the other nationalities who will not survive if they relinquish their distinctive identity and accept to live as Subalterns. The Loop Garoo Kid is a symbol of the entire society of the integrated blacks. His phantasmagoric representation helps capture the idea of history as Time instead of wrapping 
it with a mythical aura to evade the confrontation with history because it is, as Derek Walcott calls it, "the Medusa of the New World" (370). 'Booted out' of the house of his father after a quarrel, the Loop, in the middle of nowhere as he is, experiences estrangement $(Y B$ 9). In the big world, he becomes surrounded with whores and people who entertain him and assume fraternity with him only to have his money and to make fun of his cleft foot. They also ascribe to him malicious stories; nobody tries to understand him. To add to his misery, his extreme genius and amazing artistic abilities make him more and more ostracised; no tribe accepts him a member. At the end, it was the circus group, a troupe for entertainment, which accepts and saves him from loneliness. With them, he lives at ease of mind as if he had found the appropriate spot for exhibiting his artistic abilities. In their company, he may also live safe away from the malice of those who ostracise him. Evidently, taking the Africans away from their motherland to be enslaved on a foreign soil is compared to 'booting' them out of paradise. No country accepts the Africans as equal or respects their difference; as is the case with the Loop whose cleft foot makes of him a freak. The wandering circus group is a symbol of the status of the blacks over the country where they are enslaved and factionalised. Furthermore, their abilities and history become a means of entertainment and relegation; people watch them but never try to understand them.

The Loop Garoo Kid suffers from a double-subalternity because of his black skin and personal attributes that make of him a freak to everyone including the Pope as well as his Superior who hates the Loop's artistic views dubbing them 'foolishness' and labels the artists like him 'bohemian types.' The Superior, who is the Loop's only real family, destroys the Loop when he 'boots' him out. As a result, the Loop is forced to become, as he says, a "foolvagabond with the rucksack on my shoulder always on the road. That's me, the cosmic jester" 
(YB 165). Because of his family, the Loop becomes the target of the capitalist Drag Gibson and, at the end, his prisoner. The Loop confirms to the Pope:

As always - Inquisition Inquisition. I would venture to guess that your Inquisition signaled the triumph of the clerk, the bureaucrat, and the West has been in committee thing ever since. $(Y B 163)$

The Loop points out that the unjust hegemony of religion and the capitalists make him oppressed and ostracised at home and outside it, too. Probably, the circus troupe, whose members are, basically, some people with distinguished abilities, were once like the Loop. It is possible that they could find nobody to understand that they are different. As a consequence, they were bracketed from society and turned to performers so as to earn their living. To the others, they are just like circus animals; as they live to exhibit their abilities, which are considered a source of entertainment, not a rare gift. Henceforth, it is easy to Drag Gibson to make of the circus troupe a bait to entangle the Kids. The result is the destruction of the circus people and the Kids. Remarkably, the African slaves suffered from that same problem; the result was factionalising them under the constant attacks of the white man.

Reed's zeal towards representing the history of the other nationalities in the American multi-cultural society gears him to create characters functioning as representatives to the versatile races in the American society. There is the native Indian Chief Showcase, Chinaboy, and Mustache Sal, the mail order bride; they are representatives to the current status of the Red Indians, the Chinese and the Hispanic; respectively. Unlike the Loop, they contend themselves with the imposed process of depersonalisation under the sham guise of integration. In fact, they are real Subalterns who industriously fight to show to the world a 
face of mastership. Chief Showcase leads an extremely luxurious life; he has a helicopter as his private means of transportation; possesses all the means of entertainment and recreation; have numerous credit cards; and he is a friend to everybody and the one to whom everybody listens. However, Chief Showcase's current attitude is only due to being the only one left of his race. His prosperous life will continue as long as he remains a Subaltern who never fights for recognition.

Compared to Chief Showcase is Chinaboy who plays the role of the faithful and obedient servant of Drag Gibson. Chinaboy promotes his Master's dirty tricks so as to create a special dialogue between his Master and him; a dialogue that enables him to assume a place of power next to his Master's. In Drag's meeting with the cattlemen for the purpose of putting an end to the rise of the Kids, the role of Chinaboy is pinpointed:

Four bottles of Whisky were placed on the table by Drag's faithful Chinese servant, who picked a stray louse from Drag's fur coat only to put it down the cattleman's back. Drag smiled a bit, slapping his back until his hand found the bullseye [sic]. Killing the pest, he and the servant exchanged grins. (YB 19)

Chinaboy knows that he will ever be in an advantageous position as long as he assumes the role of a jester and servant; two downgrading roles convenient to the lowest levels of subalternity.

Considering Mustache Sal, she is a confirmed prostitute of a Creole origin. She accepts to get married to the old impotent Drag Gibson through mail order in hope of assuming a powerful position compared to that of the Masters. Motivated by greed, she keeps 
poisoning her husband and becomes happy when watching him rot day after another. But, the old man never dies and discovers her infidelity. After threatening her with a punishment that he cannot fulfill, Drag orders his men to "[drag] the screaming woman out of the House and [throw] her into the buckboard for the trip to the swine pit behind the gallows" (YB 113). Evidently, in the multi-cultural society of the United States, it is impossible to assume an advantageous position except through total depersonalisation. However, severe punishment and annihilation wait for whoever expects to assume a role better than the one designed to him/her; a fact that Chief Showcase and Chinaboy grasp but Mustache Sal does not.

Plainly, Reed's "effective history" of subalternity in the United Sates is remote from "submission to an epistemologically loaded relationship of power" marking the traditional effective historical investigation which makes of history a fiction. The phantasmagoric perspective facilitates the process of "making history." Reed's documentation of history, similar to Foucault's, is based upon the notion of "telling the truth today" so as to diagnose the present societal ills and offer suggestions and possibilities for alternative explanations and courses of action" (Flynn 44). In other words, expounding the history of the present, which appears as a chaos of forms, offers the Subalterns the possibility to benefit from their palimpsestic situation and, probably, to remap the scheme of the relationships of power.

Likewise, Sonallah Ibrahim's 'effective' history-making that is also concerned with 'telling the truth today' is based upon genealogical investigations ${ }^{6}$ that detect Zaat's journey from infancy up to the present and silhouette her against a rich background of events derived from newspaper clips that are accumulated from the eighties up to the present. Compared to Foulcault's, Ibrahim's history appears "grey, meticulous, and patiently documentary"; it "requires patience and knowledge of details, and it depends on a vast accumulation of source material" (Foulcault, "Nietzsche" 76-77). The history of the double-Subaltern Zaat indicates 
that 'the shocking slap on the backside' is magnified and ramified. Documenting Zaat's everyday life rituals elucidates the fact that she is oppressed by everyone as well as by a corrupt social system. At home, the unrelenting violence practiced against her undercuts her femininity. Her mother does not equip her with the necessary education that would prepare her to the most intimate moments of womanhood. Menstruation blood is a shock to her not a source of joy; as her mother is afraid that her daughter might misuse such knowledge. This explains why her mother insists on making her daughter go through the harsh experience of circumcision in fear of diversion before marriage. The result is that Zaat's sexual ability and enjoyment are forever castrated.

The series of disappointments are crowned by the real starting point of this melodrama; namely, Zaat's wedding night. Her husband thinks that the non-existence of the virginity membrane is a proof to previous sinister affairs; despite the fact that she is born without it. Such a traumatic incident, certainly, negatively influences her nuptial life forever. Whenever she is coupled with her husband, tears gush to her eyes. Her hidden and suppressed sadness at the end materialises in form of reluctance to be even touched by her husband. Perceivably, one of the sources of joy and fulfillment for any human being turns to a constant experience of pain and oppression. The destructive influence of the education of Zaat's mother does not stop at this end; during Zaat's period of engagement, her mother appoints herself a guard supervising the meetings of Zaat with her fiancée. It is strange that the jailor and the oppressor of Zaat is her mother. To understand the mother's attitude, it should be taken into consideration that Zaat's mother is a woman who bears the brunt of psychological and physical violence practiced against the Egyptian women. Hers is not an attitude of cruelty, but of ignorance and naïveté that does not allow her to confide her thoughts even to herself. These two real examples epitomise the situation of women in Egypt. 
Zaat's subalternity is not due to vermin notions only as under the male gaze she is completely lost. She is deprived of the right to express herself; Abdul Meguid always "silence[s] her with a stern look that remind[s] her of her father" (Zaat 9). Because of her future husband, her career is destroyed. Abdul Meguid obliges her to drop her university education and her dreams of a bright career by an 'uncompromising tone' declaring, "that the house would need all her time" (Zaat 9). Mishandled as she is, Zaat ends as someone who is good for nothing; someone whose abilities are checked.

She was no longer qualified for any work. She was even starting to forget the basics of reading and writing. The only thing she could do well was the housework, and even this she sometimes messed up under the stern and watchful eyes of Abdul Meguid (she would add salt instead of sugar, or vinegar instead of rosewater, or stand frozen in front of the milk pan or the coffee kanaka, unsure as to the exact moment to remove it from the flame, until the contents boiled over). (Zaat 10)

Obviously, Sonallah Ibrahim traces the history of a society that destroys its members; especially the females.

Remapping the history of subalternity and colonialism in postcolonial realms, Reed and Ibrahim do not wrap their protagonists with a shamanistic or ideal aura. The Loop and Zaat are introduced as figures that repulse their actual representation in a dissoluble form of history that is moulded from a Western-centric perspective, which confirms their subalternity. To the others, theirs is an unconventional attitude, which is considered either reckless 
insurgency, as is the case with the Loop, or apathy, as is the case with Zaat. Such an attitude is a reflection of their 'homelessness, as they are forcefully alienated from "the essence of Being's history." Martin Heidegger argues:

Homelessness so understood consists in the abandonment of being by beings. Homelessness is the symptom of oblivion of Being. Because of it the truth of Being remains unthought. The oblivion of Being makes itself known indirectly through the fact that man always observes and handles only beings. Even so, because man cannot avoid having some notion of Being, it is explained merely as what is "most general" and therefore as something that encompasses beings, or as a creation of the infinite being, or as the product of a finite subject. ('Letter on Humanism' 292).

Heidegger asserts that 'homelessness' is a feeling that is experienced by any individual when deprived of recognition. Knowing that man's interest is observing the others and handling their lives, an individual who is deprived of recognition feels that he is forgotten and therefore has no Being. This feeling becomes acute when someone is particularly disregarded or bracketed. So as to avoid granting the alienated individual any type of recognition, he/she is described according to general terms and referred to as 'something' within the course of humanity, or as 'something' created by God or by a great person. In fact, Chief Showcase, Chinaboy, Mustache Sal, Abdul Meguid and Doctor Fresh also experience 'homelessness' because they have intentionally forgotten their 'Being' along with the others who shroud them with 'oblivion'. They live without a definite concept of history. They really exist but this is not a mark of their Being. In a word, they are deprived of recognition, a destiny they willingly choose. 
All that Chief Showcase can do is keeping himself away from any real activity so as to sustain his 'homelessness'. Though he knows everything and sometimes informs against those who sustain his luxurious life in an attempt to destroy them; he cannot venture to lose all for the sake of making the others conscious of his presence; his 'Being.' He is programmed to appease himself with the crumbs that the white man offers him. He even openly and satisfactorily avows his subalternity in return for having sex with Mustache Sal. However, he makes her aware of his Being and that he is the Master of the situation when he tells her that copulating with her will be in return for not divulging to Drag Gibson that she drops some pills in Drag's drink so as to get rid of him. Beholding Mustache Sal rubbing against him and starting to unbutton her blouse, Chief Showcase asserts:

What does white folks business have to do with me; Showcase said lifting her long black skirt and placing his hand upon her creamy thighs. The white man has the brain of Aristotle, the body of Michelangelo's David and the shinning spirit of Prime-mover, how would it took [sic] for a lowy savage wretch such as me meddling in his noble affairs? Showcase said pile driving into Sal so that her spine rammed up against the wall of the porch banner and her legs wrapped about Showcase's hips. (YB 109)

Showcase gets used to and even likes to pass his life unnoticed and unrecognised. He contends himself with the role of a trickster; a role that Chinaboy also assumes. Chinaboy plays the role of the loyal and devoted servant of Drag Gibson. Yet, when Drag Gibson is announced dead, the trickster attitude of Chinaboy is dismantled as he becomes the first one 
to express great happiness and joy. Watching Drag back to life again, he checks his joy and resumes his role of utter subalternity.

As for Mustache Sal, her outer veneer of a lascivious whore using her beauty to satisfy her voracious lust does not hide the fact of her depersonalisation. She is an aimless wonderer who accepts to be treated like a bundle; a mail-order bride for Drag Gibson. Unexpectedly, she adores her role as a whore. Compared to Chief Showcase, she sells herself in return for financial gains. Despite the fact that she enacts a scheme for killing Drag Gibson, this can never be considered an action towards recognition because she searches for a recognition, which can only be granted through a high financial position that is, in turn, gained through illegal methods; the same way she does in her promiscuous sexual relationships. Chief Showcase, Chinaboy and Mustache Sal will ever be 'homeless' because they consider that it is better to remain tricksters than become recognised.

In Zaat, it seems that Abdul Meguid, similar to Chief Showcase, decides to retreat away from real social activity long ago even before proposing to Zaat. She always hears about his bravado and daring confrontations but never beholds him participating at any. Unlike Chief Showcase, he uses many techniques to gain recognition. First, he insists upon having an exquisite appearance, the "gold accoutrements: cigarette case and lighter (Ronson), ring, Old Spice aftershave, and winkle-picker shoes" (Zaat 4). Second, he shrouds himself with a hallow of superiority when he uses few English words in his conversational language, and arrogant behaviour only to convince simple-minded people, like Zaat and her family, that he belongs to the class of the Masters and not to that of the Subalterns. Growing older and older, Abdul Meguid's attitude towards his realm does not change, though his social status and standard of living tell another story. It appears that he always lives in a world of his own 
creation whose doors are only open for Zaat. He is lonely and weak outside the boundaries of his house, which is his sole sanctuary where he is the prime-mover and bravado-achiever. This fact tragically aggravates when he returns home after imprisonment. He shuts the door of his world even at the face of Zaat, his only link to real life. He experiences 'homelessness' even at home.

She [Zaat] was able to welcome home Abdul Meguid with plans laid for the future, and to give him her undivided attention. This was totally opposite of him, who seemed to be harboring a large number of ambiguous and uncertain feelings, not to mention his much-diminished size, which became specially apparent when he knelt down to pray, and when they went to bed and he curled up next to the wall, and which deteriorated even further as she prepared to perform her duty. Then she too became confused, for at first, she had felt a certain amount of relief, but this quickly turned to disappointment when he turned over and she was left staring at his back [My emphasis]. (Zaat 338).

Abdul Meguid's confrontation with the real world destroys him. For the first time, and certainly the last, he craves recognition and putting an end to his 'homelessness' when he decides to make true any of his bravado adventures. He courageously slaps back and pushes against the wall his neighbour El Shanqeety who starts the aggression. The result is total humiliation; the loss of the image that he has tried so hard to preserve in front of his wife and children; and sealed 'homelessness'.

Abdul Meguid always used to think of his being as a mark of his existence; i.e. Being. The course of events, however, reveals that this is a figment of his imagination and that this 
notion is only applicable within the circle of the family. Going out to the outer world, his Being is doubtful. He does not and cannot achieve anything he keeps promising to do; including living in an apartment that has, says Abdul Meguid in his own inconvertible way, "a balcony overlooking the street (we have to go up in the world); on the second floor (not too high, not too low); in a new building with respectable neighbours, in a clean market area, oov koors," (Zaat 5). What happens is that the flat he rents is on the fourth floor, and does not look out onto the entrance to the building. This particular feature "brought tears to Zaat's eyes because she suddenly realized that she would be deprived forever of looking out on the world" (Zaat 6). This is not the last of the series of disappointment and frustration he brings to his wife. After a while, they discover that the respectability of the 'respectable neighbours' is questionable. In addition, the 'clean market area' with the passage of time loses this attribute. In fact, Abdul Meguid remains as he is: the anonymous Subaltern.

Considering Doctor Fresh, though he returns back to his homeland, he does not feel that he belongs to Egypt anymore; he is rather happy to experience this sense of estrangement. The subject and content of his speech, the way he talks and the gifts he introduces to the others testify to the fact that he is still a dweller of the Western world. In the birthday party of Zaat's son, Doctor Fresh attempts to dominate the occasion with his knowledge as well as gifts. He enters with a box full of huge gateau together with a small shy white griffon; his gifts impress all the guests. He also proceeds to shock the attendants with his torrents of stories that make of him a figure that is totally alien to the culture from which he emanates. Similar to Mustache Sal, Doctor Fresh prostitutes his education for immediate advantages. Therefore, it is the sensitive Zaat who discovers how disgusting he is the same way his gifts are. Doctor Fresh's arrogant Western-centric attitude forces the others to go through 'homelessness' though they are among their equals and peers. He prompts every guest 
to lose his/her self-esteem and to doubt his Being. It seems that when Zaat imagines that the cat has excreted all over the sumptuous gateau, she, unconsciously, expresses a silent protest against any sort of forced 'homelessness' and subalternity.

Compared to any Slave described by Heiddeger, Chief Showcase, Mustache Sal, Chinaboy, Abdul Meguid and Doctor Fresh avoid any action conducive to recognition out of the 'Fear' or the terror of 'Death' that has become the source of oppression in human history (Heiddeger, Being and Time 263). Afraid as they are of being perished, even if this were the way to put an end to their degrading subalternity, they invent excuses to avoid fighting. Thus, they advocate ideologies, which justify their indifference towards social responsibility. They promote for what Hegel calls 'slave ideology ${ }^{17}$ which is an ideology that a Slave adopts when he is aware of the contradictions between himself and the Master and pleads that he is not ready to engage himself in a fight to death so as to gain recognition. In this case, according to Hegel, the Slave searches for an excuse to avoid fighting. Thus, he advocates an ideology on which he can justify his indifference towards social responsibility (Hegel, The Phenomenology 163). Sometimes, the 'Slave ideology' provides mental freedom to the stoic Slaves, or in postcolonial terms, Subalterns, such as Chief Showcase and Abdul Meguid. Other times, as is the case with the skeptic Slaves, it makes the Slaves, or the Subalterns, unable to understand that the reality of the type of life, which they lead, is essential for freedom; the case is applied to Mustache Sal, Chinaboy and Doctor Fresh.

In contrast, the Loop and Zaat believe that projecting their Being in action will make them transcend their reality. Compared to Heidegger, they hoard the notion that "the essence of action is accomplishment. To accomplish means to unfold something into the fullness of its essence, to lead it forth into this fullness - producere [sic]" ('Letter on Humanism' 274-75). Action is a sort of self-projection whose result puts an end to the 'Fear' of 'Death' or 
'Nothingness' that all the slaves, or Subalterns, experience; because it is a necessary condition for the revelation of one's own existence or authenticity. In consistence with Heidegger, being "towards death or dying is not a communal occurrence, and an individual must die on its own," then the experience of death and the realization of that experience "individualize human existence" (Being and Time 263). Death may be a method to shed light upon anyone's being to render it into Being; in other words, existence and recognition. Accordingly, it is the Subaltern, not the coloniser, who is the agent of historical revolution. It is worthy to mention that recognition demands an act of violence which might be transformed into a fight to death to attain self-projection leading to recognition and, hence, history-making. Thus, it is only the Subaltern who is capable of that.

Setting themselves to change the course of history, the Loop and Zaat never turn into hopeless incarnation of injustice, despite their despairing situation. They attempt to face the forces of repression and escape the limitation of their culture in a way invoking a history of resistance. The Loop Garoo Kid and Zaat create out of their difficult situations an instrument with which they put an end to their bondage and achieve independence. Hegel in The Phenomenology of Mind asserts:

This Consciousness in consequence takes a negative attitude towards the relation of lordship and bondage. Its action, in the case of the master, results in his not simply having his truth in and through the bondsman; and, in that of the bondsman, in not finding his truth in the will of his master and service. 
In any Master-Slave relationship, which is typical to that of Coloniser-Subaltern, if a Slave becomes Conscious of his Being, the Master-Slave relationship will be negatively affected. Regarding the Master, his position will not be that secure and he may not recognise himself as a Master anymore after the Slave revolts against him. As for the Slave, the 'bondsman' who revolted against his Master, he will not have the tendency to serve that Master because he has recognised a new aspect in himself other than that one of subalternity. The case is applied on Yellow Back Radio Broke-Down and Zaat; as it is 'not finding the truth in the will of their master and service' that impels the Loop and Zaat to defy their subalternity. They dedicate their efforts to the attainment of the freedom of self-consciousness. The Loop's freedom is attainable through scheming and using voodoo against the life of Drag Gibson, and Zaat's through endeavouring to change her oppressive reality at home, at work and in the various social institutions that entangle her life.

As long as Consciousness is self-determined, and the creation of the Other is no more than an externalisation of Consciousness, an Hegelian approach defying subalternity is possible, an approach that foregrounds freedom and obliterates all distinctions between externality and internality of Consciousness. "The Being of Spirit," Hegel confirms, "may be understood by a glance at its direct opposition-matter. As the essence of matter is gravity so, on the other hand, we may affirm that the substance of Spirit is freedom" (Encyclopaedia of Philosophy Sciences 141). Hegel believes that anyone has the ability to gain recognition provided that he should contradict the role he is destined to assume because such a role makes of him a static matter despite the fact that he is born to be free and to choose his path in life. It seems that both of the Loop and Zaat begin to grasp this fact after revolting against their pre-determined role of a Subaltern, who, compared to any Slave, should be bounded by 'Fear' of 'Death'. Thus, they attempt attaining freedom so as to put an end to the 'Fear' of 
'Death'; they make true that objective through self-projection which is the gateway to recognition.

The Loop Garoo Kid's scheme of resistance is: making Drag Gibson and his men Conscious of his Being. The Loop hides himself in the mountains and never directly appears, and if he does, that comes in the form of phantomic visits to those he intends to intimidate. Consequently, his name becomes widely reiterated. While Drag Gibson is celebrating with his men his success at vanquishing the Kids, the Loop appears to him, only to spoil Drag's joy. He drives Drag Gibson out of his wits to the extent that Drag madly shoots everywhere. Intelligent as he is, the Loop surrounds himself by a voodoo hallow that makes of him a legendary hero, as the others start to believe that he is a supernatural force. Knowing that the Loop is capable of voodoo magic, Big Lizzy testifies that he was in the mountains, because she found a necklace, some odd arrowheads and fishhooks while she was hunting in the mountains. Marcia, the 'hurdy gurdy girl', describes the Loop Garoo Kid, whom she sees riding off, as a "lighting taking a hiatus from nature. Looked like two ghosts were waiting for him" ( $Y B$ 85). Skinny also mentions that the Loop rides off "like a comet" after his "apparitional episode" (YB 86).

But the apparition courageously appears at the town's battleground, namely, the Purple Bar-B, the place where everybody in town meets. When the Loop steps into the bar, he startles everyone; many flee away and the cowpokes freeze. The Loop's scheme of resistance starts with vanquishing the major coloniser-surrogate, the Marshal, who helps perpetuating the tyrannical hegemony of Drag Gibson. In a confrontation between the Loop and the Marshal, the latter appears too clumsy compared to the Loop who humiliates him in front of everyone. During this fight, the Loop, borrowing the method of professional 
cowboys, strips the Marshal not only of his clothes, but of his dignity and hegemony; he fights the West with its same weapon; this is the Slave's revolt against the Master. The humiliated Marshal, consequently, decides to leave the town as if announcing the victory of the Loop and avowing his mastery, at least of the situation.

The Loop's knightly appearance and resistance in the bar puts an end to the rumours that make of him an apparition. His self-projection and unrelenting resistance declare to everyone that it is not only ghosts or supernatural forces that can defeat tyranny and injustice, a revolting Subaltern can also do. Getting rid of unjust cruel authority, incarnated in the character of the Marshal, the Loop turns to the other type of spiritual authority promoting the subalternity of the common people. The representative of such an authority is the Preacher Rev. Boyd. Attempting to defeat the Loop by superstition, the Preacher brings forth his crucifix and takes out of his pocket a mirror aiming it at the Loop's face so as to exorcise him; as if the Loop were a ghost. Yet, the Loop wakes him up by severely hitting him. The Loop desires to give the Preacher a lesson that he should not dupe the others by faulty sermons and false information designed according to the necessity of the situation. In short, the Loop's battle stops perpetuating false hegemony, either secular or religious.

Manifestly, the battle between the Loop and the emblem of the tyrannical colonial power, Drag Gibson, starts long ago. Using his voodoo capabilities, the Loop designs an infallible scheme of recognition aiming at the destruction of the hegemony of Drag Gibson. The Loop directly attacks Drag using different techniques; he uses voodoo spells to make him rot or to transform Drag's former dead wife into a python that the Loop later uses as a weapon against his oppressors. It is voodoo that offsets the centralised authority and the evil of Drag Gibson. Voodoo is a kind of historicising; in Yellow Back Radio Broke-Down, 
voodoo revives the past and creates a place for the Subalterns in the present. Reed takes from his legacy what might put an end to the Loop's subalternity. In fact, the Loop's practices are not to be defined as evil, they are his way to a syncretic, multicultural, and decentralised world. Perceivably, through Voodoo, Ishmael Reed moves easily from an age to another or mingles the past with the present. "Voodoo," according to Reed, "is the perfect metaphor for the multiculture. Voodoo comes out of the fact that all these different tribes and cultures were brought from Africa ... Voodoo also teaches that the past is present" ("A Conversation with John Domini," Conversations 124). Reed invokes an atavist spectacle in which he mixes voodoo with African legends so as to create, like freedom fighters, a modern legend that engenders a spirit of resistance to the contended integrated bourgeoisie.

Compared to any coloniser attempting to stifle a revolution, Drag designs "a plan to get rid of this spook [the Loop Garoo Kid] once and for all," says Drag Gibson. Therefore, he hires a man "of whom it was said, 'that boy can handle a pistol fasten a frog can lick flies'"(YB 114). Drag Gibson hires a proxy force, in modern terms, a guerrilla man, to finish the Loop who has humiliated him. Ironically, it is the Loop who comes out of the battle victorious; as he defeats the killer, the guerrilla man, helped by the great python, Drag's enchanted dead wife, who is another oppressed soul that the Subaltern the Loop fills with power of resistance and revolt. About to leave, the Loop cynically demands a man-to-man confrontation with Drag, of course, after he sends away with his bravado all those who help promote Drag's tyranny. Undoubtedly, Drag recoils from such a confrontation. The Loop's resistance makes the other, all the time, and conscious of his Being. Resistance and selfrecognition assert that the Loop does not occupy all the time the position of a Subaltern. This is confirmed when the Loop sleeps with Drag's mail order wife at their wedding night. The 
Loop makes her shout his name as loud as everybody can hear, totally disrespectful of her husband.

Regarding Zaat, in her battle for recognition, she never stops resisting the negative influence of her husband and her work mates who Ibrahim calls the 'transmission machines.' Working is not Zaat's idea, however, going out is her first step towards recognition. At home, her income becomes a significant contribution to the house's upkeep. Work also makes her leave the microcosm to which she somehow cannot, up till the end, belong. Her weapons in the battle for recognition at home and work are so simple: two bags, one for sandwiches and pickles and the other for the 'transmission' material. Recognition at work demands that she carefully listens to whatever is said outside the boundaries of work to repeat it at the premises of work the following day. But that strategy has a momentary success as Zaat, in many other days, has no clue to anything new that she might say to the 'transmission machines', as a result, they, instantly, ignore her. Developing her means, Zaat, practices to tell a story episodically or to handle it from different aspects, which gives her the benefit of telling the story on the span of many days, and in each day, it appears as if she is telling an entirely new one. Zaat, thus, assumes the position of a good storyteller in the oral tradition. The battle for recognition at work forces her also to memorise the jokes she hears from her daughter to tell them the following day at work or to change the way she looks, such as wearing make-up or putting on a veil. However, the process is reversed with her husband. She makes of the material she collects from work, whether newspaper or magazine clips or the stories of the 'transmission machines', a medium of communication with Abdul Meguid.

Nevertheless, the fight for compelling the others to be Conscious of her Being materialises in her desire to take part in the march of demolition and construction in order to 
be at a position equal to that of her neighbours and to qualify herself to communicate with them. She struggles to urge her husband to pay with her visits to the shops and bring plumbers or specialists. At the end, her efforts pay, she raises money by means of making a cooperative. Her husband's resistance to communicate is met by increasing signs of dissatisfaction and even quarrels as is the case of the incident of the sewing machine that Abdul Meguid causes to fall to the floor. The reaction of Zaat is a big fight with him, which contradicts her mellow nature followed by leaving the house. Zaat's most courageous decision, which enables her to prolong the period of communication with both the 'transmission machines' and her husband, is getting pregnant. That is her way to enter a world of communication, victory, and, possibly, leadership. Pregnancy is her way to absorb her ever-increasing state of dissatisfaction. Moreover, she found in the royal newcomer a totally unique opportunity to achieve a more significant goal, which was to register a point on the march of demolition and construction far more valuable than those gained from the sarmaka (putting down ceramic tiles) or the kambasha (fitting a modern combination toilet) or the kandasha (installing air conditioning). (Zaat 143)

Zaat constantly attempts to syncretise her inner realm with the outer one that appears strange to her so as to create another centre for her Being.

Zaat's desire to escape her Subaltern position at the margin so as to penetrate to the class of Masters is rooted in the latent belief that anything is subject to continuous change. This materialises in her daring scheme to struggle against corruption in society, at large. Buying a Greek olive tin and making sure that its expiry date is still two years away, she is shocked when she discovers, after peeling off the sticker of the expiry date as she washes the tin, that the contents have expired long ago. Motivated by Himmat's reciting of the 
declaration of principles, and Zaat's daughter's quoting the Tradition of the Prophet that calls a believer to set right an abomination if he or she witnesses it, Zaat, filled with zeal, directly heads to the Health Office where the employees are reluctant to receive citizens who want to do their moral duty. The specialist tells her that she would have to do so at the police station. The officer in the police station does not welcome her attempt and reluctantly writes for her the report that she should introduce to the Health Office. Heading once more to the Health Office, she has to bear the brunt of red tapes and evasive employees who are unwilling to perform their jobs or, rather, reap their joy out of watching the others suffering. However, her enthusiasm does not wane and victoriously she presents the report, along with the correction certificate. As a consequence, she obtains the authorisation of the ministry, a last step carried by Himmat. Yet, the result is sealed frustration as nothing happens and everything remains as before without the slightest change. Perceivably, Zaat's diligent attempts to change her predetermined Subaltern situation seem too strange for the others who undermine her attempts to struggle against that mortifying process of depersonalisation in which she is confined. Her frustration makes her unable to discern whether she is a native who has got rights to preserve or a person existing on a strange land. Expounding such a puzzling situation, Fantz Fanon asserts, "If psychiatry is the medical technique that aim to enable man no longer to be a stranger to his environment, I owe it to myself to affirm that the Arab, permanently an alien to his own country, lives in a state of absolute depersonalization" (Toward the African Revolution 52-53). Fanon explains that the Arabs feel that they live in a strange land; this feeling produces a dichotomy in the psychological status of the individual when beginning to suffer from depersonalisation. Certainly, the reason behind such a psychological dichotomy is the Arabs' continuous subalternity to the colonising powers who have occupied the Arab world for long eras. Therefore, the Arabs cannot get rid of subalternity and feeling with 
estrangement over their homeland. Furthermore, any attempt to change their pre-determined role, which is that of a Subaltern, is criticised by the natives themselves.

Notwithstanding, the Loop Garoo Kid and Zaat are embroiled in another fight other than that of Consciousness in which they fight against their oppressors. The main battlefield which hurls them, somehow, into psychological dichotomy is that between Consciousness and Being that, according to Hegel, stands at oppositions which are identical and different and contain each other as is the case with the Loop and Zaat whose subalternity as beings contrasts with the Consciousness of the Other of their Being; this attitude makes of them a fearful figure; i.e. a Master. Subalterns as they are whose Being is recognised by the Other, the Loop and Zaat become pseudo-Masters and pseudo-Slaves (Hegel, The Phenomenology 251). Attaining the objective for which they embroil themselves in a constant labour, they become in a position of power. Henceforth, it can be said that the Loop and Zaat could change the designed course of their personal history. They become pseudo-Masters because of the social prejudices and concerns into which they and their likes are placed. Yet, the Loop's situation is better; his labour grants him, to some extent, individuality, which is a quintessential step for uprooting subalternity. On the other hand, Zaat's position as a woman in a world that does not welcome her likes denies her the right of individuality.

Obviously, history appears in Yellow Back Radio Broke-Down and Zaat as a motif charging the power of the protagonists who use the legends of the past and the modern world to resist the corrupt Masters. Consistently, history gears "the reversal of the relationship of forces" (Roth 32). Escaping subalternity requires assiduous and diligent schemes of selfprojection, which, in the course of their personal history, pinpoint the 'Being' of the Subaltern and, hence, urge the Master to recognise his/her Being. Subalterns, like the Loop and Zaat, 
should not surrender in the battle for recognition because the more they become involved in life, the more difficulties they face. Terry Eagleton argues that:

As with all such philosophies of the subject from Hegel to the present, this monadic subject must somehow curiously preexist its own process of materialization - must be equipped, even now, with certain highly determinate needs and desires, on the model of the autonomous human personality. (28)

Visibly, the Loop and Zaat possess such 'determinate needs and desires' which will enable them to attain individuality; in other words, 'autonomous human personality'. Their lives are a series of acts of aggression to change the course of history. As for Chief Showcase, Chinaboy, Mustache Sal, Doctor Fresh and Abdul Meguid, each has a different vision. They feel safer when they retreat more and more from social life; show no signs of resistance, except occasionally in a very undercurrent form; and recoil from the participation in social action. The like Subalterns are a direct reason for the ramification of subalternity and promoting tyrannical practices that deform the history of a nation. They do not feel that they belong to the country to which they are affiliated. Furthermore, they are not sure whether they belong to the realm where they live; they voluntarily decentre their history and choose 'homelessness'.

Instead of refurbishing resistance with other fights for recognition, the endings of Yellow Back Radio Broke-Down and Zaat, compared to any real historical course of events, mark the defeat of heroic figures confirming that history is a succession of epistémes and that each age has its unique epistéme. Therefore, the defeat explains the change from one epistéme to another, or, in other words, the movement from one epoch of resistance to another. Attacked by a multiplicity of forces in his unrelenting course of resistance, the Loop Garoo 
Kid ends up in jail as the Pope informs against him. In response, the Loop frustrates the Pope's plan, which is meant to compel the Loop to accompany him to Rome, by refusing the offer and willingly accepting to die at the guillotine. The Loop prefers to be remembered as a heroic rebel who finds genuine liberty in death for the freedom of thought and love of art. He seeks recognition through projecting that he is not stamped with 'Fear' of 'Death' the same as any Slave/Subaltern is. Yet, this endeavour is also frustrated by the sudden appearance of the Seven Cities of Cibola towards which everybody runs including the executioner. The Loop's willingness to die is his last trick of self-projection in the fight for recognition; a trick in which he will be a Master. Once more, his attempts to attain the freedom of expressing his artistic views are frustrated. Thus, he has no choice except to involuntarily return back to the labyrinth of subalternity and inability to find people willing to understand his difference. Remarkably, many changes take place: the return of the Kids along with the sudden appearance of the technological anarchoparadise of the Seven Cities of Cibola, the death of the tyrant capitalist Drag Gibson as well as the corrupt government agents, and the unity of objective which all the classes collectively experience when running towards such a technological anarchoparadise. Yet, all these changes do not mean the victory of the Loop as everything happens beyond his control and willingness. As a consequence, he accepts what he has previously rejected; as he "rode rapidly over the Mountain and off into the distance in an effort to catch up with the Pope's ship" [My emphasis] (YB 174). In brief, subalternity to a dominant hegemonising power is inescapable, but the situation is getting better as the appearance of the technological anarchoparadise marks the advent of a new phase of progress in such a multicultural society; a new epistéme of power.

Likewise, Sonallah Ibrahim's Zaat is trapped in the vicious circle of corruption tarnishing any sign of hope or aspect of beauty, compared to the huge sumptuous gateau of 
Doctor Fresh that is tarnished with the cat's excretion. Zaat triumphs in many aspects: her husband's masterful aura is subdued after he returns home back from prison and she also exorcises the genies haunting her. However, Zaat does not enjoy her triumph. On the contrary, she relapses once more in her former prosaic course of life and subalternity; the same way she used to before her fights for recognition. Returning back from work in the blistering sun, she stops off at the fish shop, which has been opened by a public sector company at the corner of the street. The cleanliness of the saleswoman attracts her. No sooner does she order fried fish and herring than she discovers that the woman's sense of cleanliness does not extend beyond the floor. Devoid of any sense of rebellion, Zaat declines from protesting; "she does not have the strength to speak" (Zaat 341). It seems that Zaat's former experience with the 'olive tin' negatively influences her will for self-projection.

Frustration, pain and despair materialise when Zaat discovers when she returns back home that she has reached the phase of menopause; namely, the phase when a woman is commonly regarded as sterile and old. Unpacking the fish, she discovers that the fried fish is only two pieces of inedible fish, as for the herrings they are rotten, but the vendor soaked them in vinegar to conceal the change in taste and then repacked them with new labels showing the expiry dates. This explains why they are cheaply sold. Evidently, corruption does not only exist among the common people or foreign sources, as in the canned olive episode, but it is also there among the hegemonising powers and senior officials. As for Zaat's reaction, it becomes complete compliance. With very cool nerves, she dumps the bad fish. She does not think anymore of going to the fish shop to have her money back or to report against the fish shop. The experience brings to her mind the memory of the wasted efforts and humiliation she had earlier endured. Furthermore, she figures out what the duty officer would say to her: "Rotten fish? So don't eat it then". She only rebukes herself for not 
inspecting the contents before leaving the shop, though that would not have much changed the situation. She says to herself:

He was right. It was a trivial issue. Extremely trivial. She felt the tears well up in her eyes and threw the fish and herrings in the rubbish bin. Then she pulled herself together, left the kitchen, and headed with slow heavy steps towards the refuge of tearful withdrawal: the lavatory [My emphasis]. (Zaat

Zaat ends up as she begins: the suppressed Subaltern who is not allowed to express her feelings. To escape her horrible reality that is full of endless series of disappointment, betrayal, failure and imposed solitary, a series that is best described as filth, she has to take refuge in a really filthy place; the 'lavatory.' Filth and sliding into the mire of horrible life is an inescapable end to her epistéme of power.

Ibrahim's Zaat reveals a pessimistic history. Although the Egyptians were able years ago to decolonise their land, subalternity is still a dissoluble fact that is so difficult to eradicate. Zaat, by the end of the novel, is entirely shattered; knowing that her final abode and rest place is filth. Indeed, she wades into endless fights, resists as hard as she can, modernises her house by participating, though with a tiny share, at the march of demolition and construction, and, above all, develops her abilities that have been checked under social circumstances and the male gaze. In short, she makes of herself a Stuart Hall's model of "a fragmented, decentered human agent, an agent who is both 'subject-ed' by power and capable of acting against those powers" (156-57). The surprise is that it seems that all her efforts are in vain. Her never drying tears create evidence to her eternal pain and inability to gain 
recognition so as to put an end to her subalternity. Unlike the Loop who has people to help and love him, Zaat lives so lonely and alienated. She suffers from chronic 'homelessness'. Her unyielding power of resistance is, constantly, smashed so is the case with the revolutionary transformation of herself and her surroundings.

Remapping the postcolonial history of the African Americans and the Egyptians in Yellow Back Radio Broke-Down and Zaat, respectively, requires documenting chaos of forms so as to produce an effective history. Both novels create an atavist spectacle; Yellow Back Radio Broke-Down gives rise to the African voodoo practices, and Zaat to the rituals of birth, circumcision, bringing up females, wedding night, exorcism of genies and birthday parties as well as the rituals of the everyday life in common Egyptian households; all of these produce what might be metonymically called an Egyptian voodoo. Such spectacles urge the Other, whether in African American or Egyptian societies, to recognise the culture and the practices of both societies without blurring them with Westerncentric perspectives. Debunking the uniform pattern of colonialism, both novels dismantle systematic schemes of resistance which objective is self-projection that would stir the Master's Consciousness of the Being of the Subaltern. Documenting an effective history in Yellow Back Radio Broke-Down pinpoints the emergence of significant epistémes of power in spite of prevailing injustice. Nonetheless, in Zaat, resisting subalternity is curbed by corruption on all levels which, in turn, marginalises any improvement to the general situation. 
Notes

${ }^{1}$ Heidegger believes that 'Being' cannot stand for 'being,' and vice versa, as the former indicates not only the assertion of the existence of a human being but also the others' consciousness of that individual. As for 'being,' it means either a human being or refers to an entity. [For more information see Heidegger, Martin (1927). Being and Time. (trans.) John Macquerrie and Edward Robinson. London: Blackwell, 1997.]

${ }^{2}$ Jose Rabasa argues that history is evident through the metaphor of the 'palimpsest' that was used for mapping the world. Actually, the colonisers applied the same technique of erasures and overwritings for remapping the history of the colonised nations. [For more information see Rabasa, José (1993). "Allegories of Atlas." Postcolonial Studies Reader. (eds.) Bill Ashcroft et al. London: Routledge, 1995. 358-64.]

${ }^{3}$ Genealogy is one of Foucault's morphological strategies which search out the changing structure of diverse phenomena. The term genealogy implies the political function in which history is the reversal of the relationship of forces. An historian can undermine the present by reversing the images of the past. To perform genealogical investigation, Foucault requires the historian to go back in time until a difference is located. [For more information see Roth, Michael (1981). "Foucault's History of the Present." History and Theory 20: 32-46, and also see the special issue on Foucault of Humanities in Society 3(Winter 1980), with contributions by Michael Sprinker, et al.]

${ }^{4}$ According to Ngugi wa Thiong'o, freedom fighters appeared in Kenya during the Mau Mau armed struggle, which Kenyan peasants had to wage against British colonialism. The national emergency revealed not only the physical violence which the colonial power enacts against 
the natives, but also a cultural one inflicted upon their consciousness. Against this background, the struggle of the Mau Mau freedom fighters had cultural aspects. Ngugi wa Thiong'o contends, "They [the freedom fighters] rediscovered the old songs - they had never completely lost touch with them - and reshaped them to meet the new needs of their struggle. They also created new songs and dance with new rhythms where the old ones were found inadequate" (Ngugi Wa Thiong'o, Homecoming 30). [For more information see Wa Thiong'o, Ngugi (1972). Homecoming: Essays. London: Heinemann, and also see Wa Thiong'o, Ngugi (1981). Writers in Politics: Essays. London: Heinemann.]

${ }^{5}$ I will always refer to Reed's novel Yellow Back Radio Broke-Down as YB

${ }^{6}$ Chinua Achebe mentions that some of the natives began to acquire European education to "challenge Europe's presence and position in their native land." The like natives urged the creation of the theory of 'the man of two worlds' in which the native despite falling under European influences, he could never truly absorb them, and in the time of need he would discard his affiliation to such a world for the sake of defending his mother land. Yet, Achebe thinks that such a theory is faulty; he asserts, "Now, did this mean that the educated native was no different at all from his brothers in the bush? Oh, no! He was different; he was worse" ("Colonialist Criticism" 58). [For more information, see also Achebe, Chinua (1988). Hopes and Impediments: Selected Essays. London: Heinemann.]

\footnotetext{
${ }^{7}$ Hegel calls such an ideology 'slave ideology'; it entails the concepts of Stoicism, Skepticism and Unhappy Consciousness. In Stoicism, human freedom is internal as a mental property having no external content. A stoic salve is passive and bored. In Skepticism, the slave does not think that the reality of the external content to be essential for freedom but instead he
} 
becomes skeptic about it. As for Unhappy Consciousness, it refers to religion. A religious slave is not interested in solving social contradictions. He believes that true equality, justice and freedom are found in the after life where all human beings become equal in the eyes of the supreme master. [For more information see Kojève, Alexander (1934). Introduction to the Reading of Hegel. (trans.) James H. Nichols, Jr. London: Basic Books, 1969. 


\section{Works Cited}

"The flying drapes of the Kaabah." Eurozine Review (Jul. 2007). Eurozine Review 25 Sept. 2007 <http://eurozine.com/authors/ibrahim.html>.

"Zaat by Sonallah Ibrahim." Complete Review (2007). The Complete Review. 25 September 2007 <http://www.complete review.com/reviews/egypt/ibrahims.htm\# basic>.

Achebe, Chinua (1974). "Colonialist Criticism." Postcolonial Studies Reader. (eds.) Bill Ashcroft et al. London: Routledge, 1995,W pp. 57-61.

Bhabha, Homi K. (1985). "Signs Taken for Wonders." Postcolonial Studies Reader. (eds.)

Bill Ashcroft et al. London: Routledge, 1995, pp. 29-35.

--- (1986). "Remembering Fanon: Self, Psyche and Colonial Condition." Remaking History.

(eds.) B. Kruger and P. Mariani. Seattle: Bay Press, 1989, pp. 140-57.

--- (1990). " Dissemination: Time, Narrative, and the Margins of the Modern Nation."

Postcolonial Studies Reader. (eds.) Bill Ashcroft et al. London: Routledge, 1995, pp. 176-77.

--- (1984). "Of Mimicry and Men: The Ambivalence of Colonial Discourse." October 28, pp. 125-33.

Chakrabarty, Dipesh (1992). "Postcoloniality and the Artifice of History." Postcolonial Studies Reader. (eds.) Bill Ashcroft et al. London: Routledge, 1995, pp. 383-89. Domini, John (1977). "Ishmael Reed: a Conversation with John Domini." Conversations with Ishmael Reed. (eds.) Bruce Dick and Amirijit Singh. Jackson: University Press of Mississippi, 1995, pp. 128-43.

Eagleton, Terry (1089). The Ideology of the Aesthetic. Oxford: Basil.

El Khouly, Mohamed (2004). "Akher Zaman." Al Arabi (Jun), 88. 
Ewig, Jon (1978). "The Great Tenure Battle of 1977." Conversations with Ishmael Reed. (eds.) Bruce Dick and Amirijit Singh. Jackson: University Press of Mississippi, 1995. pp. 119-36.

Fanon, Frantz (1952). Black Skin, White Masks. (trans.) Constance Farrington. New York: Grove Press, 1968.

--- (1969). Toward the African Revolution. (trans.) H. Chevalier. New York: Grove, 1988. Flynn, Thomas (1994). "Foucault's Mapping of History." The Cambridge Companion to Foucault. (ed.) Gary Gutting. Cambridge: Cambridge University Press, pp. 20-64. Fouacult, Michel (1976). "Two Lectures." Critique and Power: Recasting the Foucault/Habermas Debate. (ed.) Michel Kelly. Cambridge: MIT Press, 1994, pp. 1568.

--- (1971). "Nietzsche, Genealogy, and History." The Foucault Reader (ed.) Paul Rabinow. New York: Pantheon Books, 1984. pp. 69-97.

--- (1972). The Archeology of Knowledge. (trans.) A. M. Sheridan-Smith. New York: Pantheon.

Hall, Stuart (1988). "New Ethnicities." Stuart Hall: Critical Dialogues in Cultural Studies. (eds.) David Morely and Kuan-Hsing Chen. London: Routledge, 1996. pp. 141-75. Harris, Wilson (1981). "The Limbo Gateway." Postcolonial Studies Reader. (eds.) Bill Ashcroft et al. London: Routledge, 1995. pp. 378-82.

Hassen, Abdalla F. (2003). "Balck Humor in Dark Times." Worldpress.org (Jun 19). Worldpress.org 25 Sept. 2007 <http://www.worldpress.org/Mideast/1205.cfm>. Hegel, G. F. W. (1985). Encyclopaedia of Philosophycal Sciences. (trans.) William Wallace. London: Oxford University Press. pp.131-45.

--- (1807). The Phenomenology of Mind. (trans.) J. B. Baillie. New York: Harper Torch Book, 1967. 
Heidegger, Martin (1947). "Letter on Humanism." From Modernism to Postmodernism: An Anthology. (ed.) Lawrence E. Cahoone. Cambridge, Massachusetts: Blackwell Publishers Ltd., 1996. 274-308.

Howell, Patrick A. (2018). "Ishmael Reed: Interview." Into the Void (Apr. 14 ${ }^{\text {th }}$ ). intothevoidmagazine.com 5 December 2018 <https://intothevoidmagazine.com/2018/04/14/ishmael-reed/>.

--- (1927). Being and Time. (trans.) John Macquarrie and Edward Robinson. London: Blackwell, 1997.

Ibrahim. Sonnallah (1992). Zaat. (trans.) Anthony Calderbank. Cairo: The American University in Cairo Press, 2006.

Kojève, Alexander (1934). Introduction to the Reading of Hegel. (trans.) James H. Nichols, Jr. London: Basic Books, 1969.

Marx, Karl and Friedrich Engels (1848). "Bourgeois and Proletarians," Section One of Manifesto of the Communist Party." From Modernism to Postmodernism: An Anthology. (ed.) Lawrence E. Cahoone. Cambridge, Massachusetts: Blackwell Publishers Ltd., 1996, pp. 91-101.

Menon, Nirmala (2016). "Representing the Postcolonial Subaltern: A Comparative Reading of Three Subaltern Narratives by O.V. Vijayan, Arundhati Roy and Mahashweta Devi." Remapping the Indian Postcolonial Canon. London: Palgrave Macmillan. pp. $35-70$.

O'Brien, John (1972). "Ishmael Reed." Conversations with Ishmael Reed. (eds.) Bruce Dick and Amirijit Singh. Jackson: University Press of Mississippi, 1995, pp. 25-40.

Rabasa, José (1993). "Allegories of Atlas." Postcolonial Studies Reader. (eds.) Bill Ashcroft et al. London: Routledge, 1995, pp. 358-64.

Reed, Ishmael (1969). Yellow Back Radio Broke-Down. Illinois: Dalkey Archive Press, 2000. 
Roth, Michel (1981). "Foucault's History of the Present." History and Theory 20, pp. 32-46.

Shafy, Haitham Abdel (2017). "Interview with Sonallah Ibrahim: The writer of Modern Arab life" Raseef 22 (May 17 ${ }^{\text {th }}$ ). raseef22.com 1 Dec. 2018 <https://raseef22.com/en/culture/2018B/05/17/interview-sonallah-ibrahimwriter-modern-arab-life/>.

Walcott, Derek (1974). "The Muse of History." Postcolonial Studies Reader. (eds.) Bill Ashcroft et al. London: Routledge, 1995, pp. 370-74.

Wa Thiong'o, Ngugi (1972). Homecoming: Essays. London: Heinemann. 